Western University Scholarship@Western

Research Program. Impact of the Public Sector on

Research Program. Impact of the Public Sector on

Local Economies Discussion Papers

Local Economies

1977

\title{
Railway Externalities and Residential Property Prices
}

Larry C.L. Poon

Follow this and additional works at: https://ir.lib.uwo.ca/economicsipsle_dp

Part of the Economics Commons

Citation of this paper:

Poon, Larry C. L.. "Railway Externalities and Residential Property Prices." Research Program. Impact of the Public Sector on Local Economies Discussion Papers, 018. London, ON: Department of Economics, University of Western Ontario (1977). 


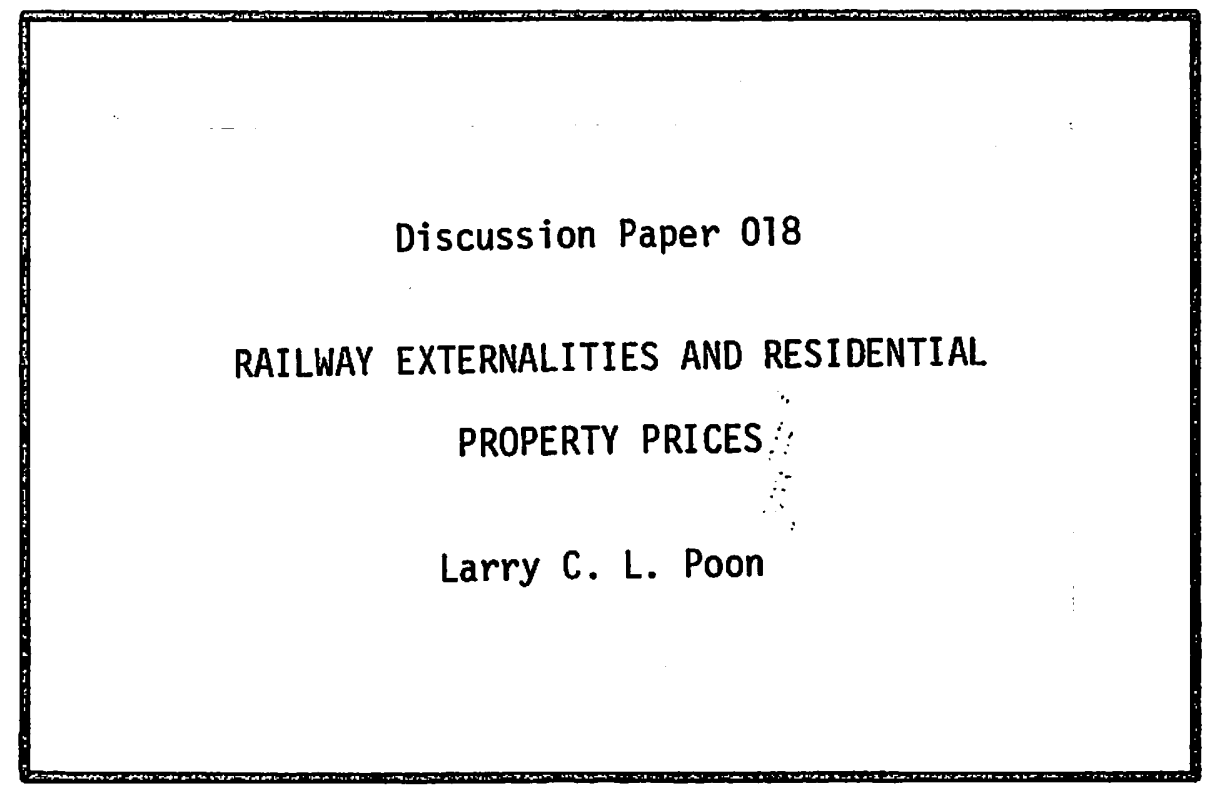

\section{RESEARCH PROGRAM: IMPACT OF THE PUBLIC SECTOR ON LOCAL ECONOMIES}

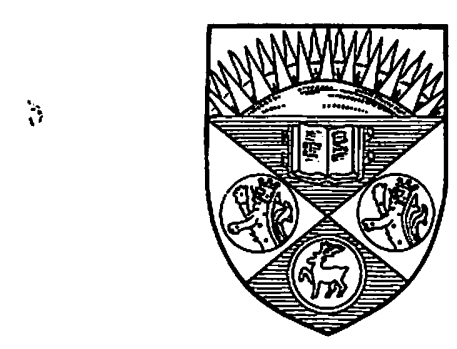

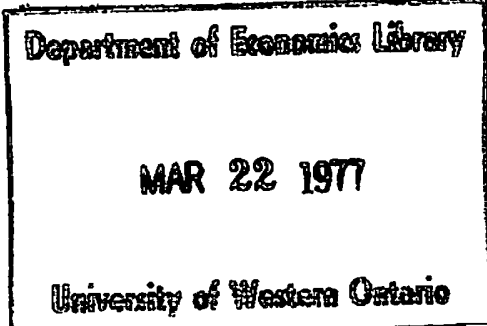

Department of Economics The University of Western Ontario London Ontario Canada 


\title{
Discussion Paper 018
}

\section{RAILWAY EXTERNALITIES AND RESIDENTIAL}

\section{PROPERTY PRICES}

\author{
Larry C. L. Poon
}

February 1977 


\title{
RAILWAY EXTERNALITIES AND RESIDENTIAL
}

\section{PROPERTY PRICES}

\author{
Larry C. L. Poon*
}

\section{A. INTRODUCTION}

Many urban areas in North America are debating whether to relocate the interurban railways which pass through their centres, and the Canadian federal government has recently established a program to subsidize such relocation projects. One of the potential social gains of urban railway relocation is the elimination or reduction of railway air, noise, and "visual" pollution in adjacent residential neighbourhoods. The purpose of this paper is to estimate the social gains from removal of railway pollution in residential areas in London, Canada. 1

We begin in section two by presenting the conceptual framework. In section three we report a case study of the effect of railways on residential property prices in London, Canada.

\section{B. THEORETICAL ANALYSIS}

\section{Railway Externalities and Property Values}

Railways impose air, noise, and "visual" pollution on people in their neighbourhoods. Hence, the removal of the railways will confer benefits on present and future residents in these areas. The value of the benefits is the amount that these people will be willing to pay for removal of the railway. Suppose there are $R$ people and individual $i$ is willing to pay WTP it dollars during period $t$. Then the aggregate discounted value of benefits is 


$$
B=\sum_{t=1}^{\infty} \sum_{i=1}^{R} \frac{\text { WTP }_{i t}}{(1+r)^{t}}
$$

where $r$ is the discount rate per time period.

It is impossible to measure B directly by asking people what they would be willing to pay. Among other things people may not reveal their true preferences, and the questionnaire approach may therefore be unreliable.

Under certain circumstances, however, an indirect measure of the benefits due to removal of spillovers may be derived from data on property values. Use of such data is appropriate to the extent that externalities are capitalized in property values. The available evidence from empirical studies suggests that externalities are, at least partially, capitalized. ${ }^{2}$

However, only under rather restrictive assumptions does the difference in property values between two areas provide an accurate measure of willingness to pay for removal of spillovers. ${ }^{3}$ Suppose that properties in two areas are alike except that railways impose externalities in one area. Under perfect competition and with perfect mobility of households, the difference in property values (per property or per acre) between the two areas prior to railway relocation will measure the willingness to pay for removal of the externalities by the marginal household. Only if all households living in the area affected by railway externalities have the same willingness to pay for removal of the externalities as the marginal household will the difference in property values provide an accurate basis for calculating the aggregate willingness to pay for removal of the externalities. In fact, one would expect that most of the households living in the area affected by railway externalities would not be willing to pay as much as the marginal household for removal of the externalities, since the competitive market 
will allocate polluted properties to those whose willingness to pay for avoidance of pollution is least.

Suppose we rank the combined population of the two areas according to increasing willingness to pay per acre to remove the pollution. JK in Figure 1 indicates the marginal willingness to pay per acre as a function of number of acres of polluted land. The person who cares least is willing to pay $0 \mathrm{~J}$ per acre and the person who cares most will pay QK per acre. $O Q$ is the total supply of land which is composed of OF acres of polluted land and FQ acres of non-polluted land. The competitive equilibrium rent differential between the two types of land is $\mathrm{OH}$, and those willing to pay less than $\mathrm{OH}$ will occupy the polluted land. The total willingness to pay for removal of pollution by those living on the polluted land is indicated by OFGJ. However, the difference in the value of the OF acres at the two prices is OFGH, which will normally exceed OFGJ.

The same conclusion can be reached by following an alternative approach developed by Freeman (1974). Freeman was concerned with property values and air pollution. His model can be used to illustrate the relationship between property values and railway externalities.

Assume that the market for residential properties is in equilibrium and that

$$
V=V(Q, \ldots) \text {, }
$$

where $V$ is the market value of a property, which is a function of distance from the railway $(Q)$. Figure $2 a$ shows one possible form of this partial relationship. $Q^{*}$ is the distance from the railway at which the externality becomes zero.

Figure $2 b$ shows the marginal purchase price function, $R(Q) \equiv V^{\prime}(Q)$. 
Figure 1

Demand for and Supply of

Railway Polluted Land

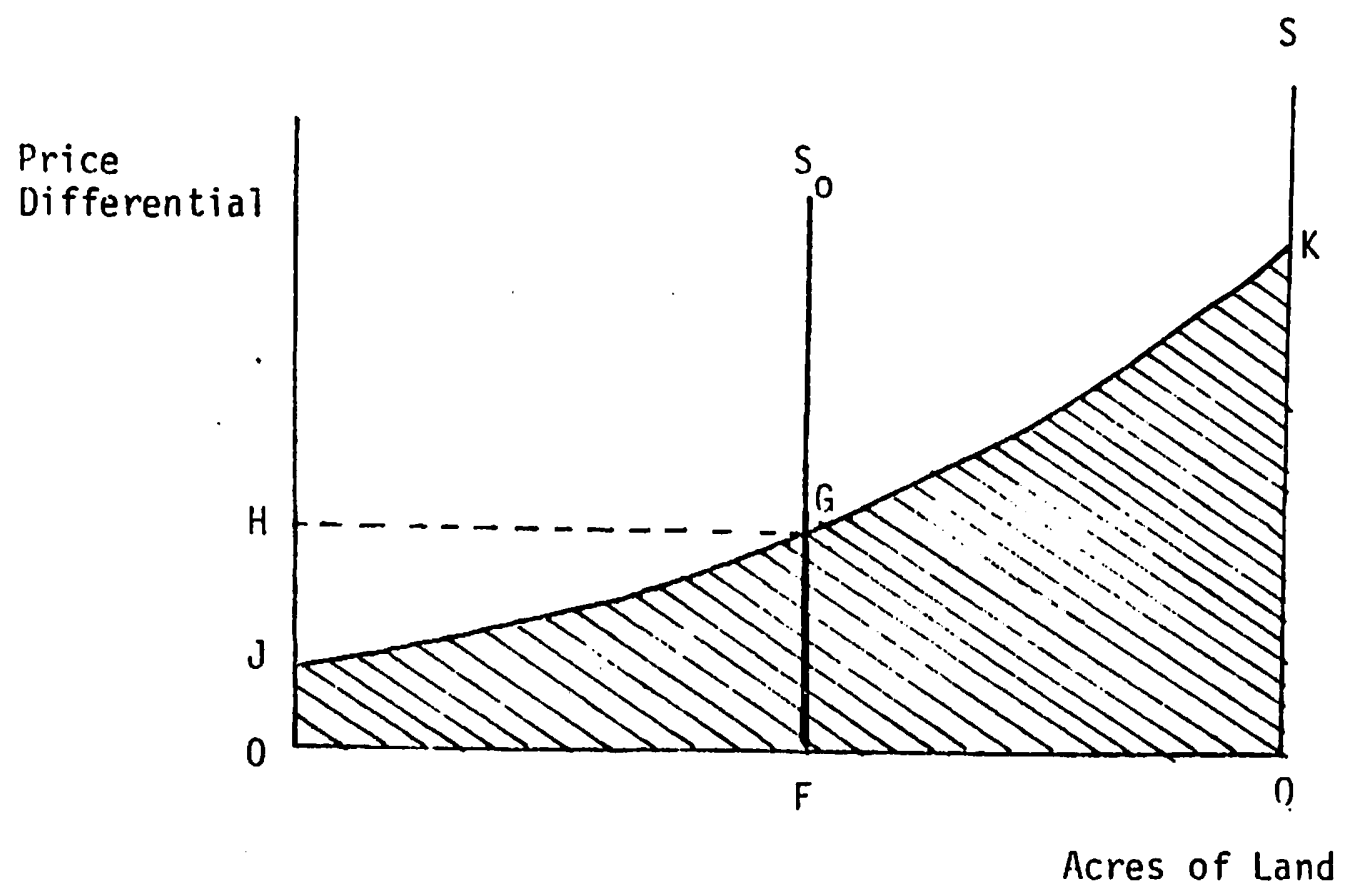


Figure 2

Relationship Between the Property Valuation Function and Willingness to Pay for Distance from Railway

(a)

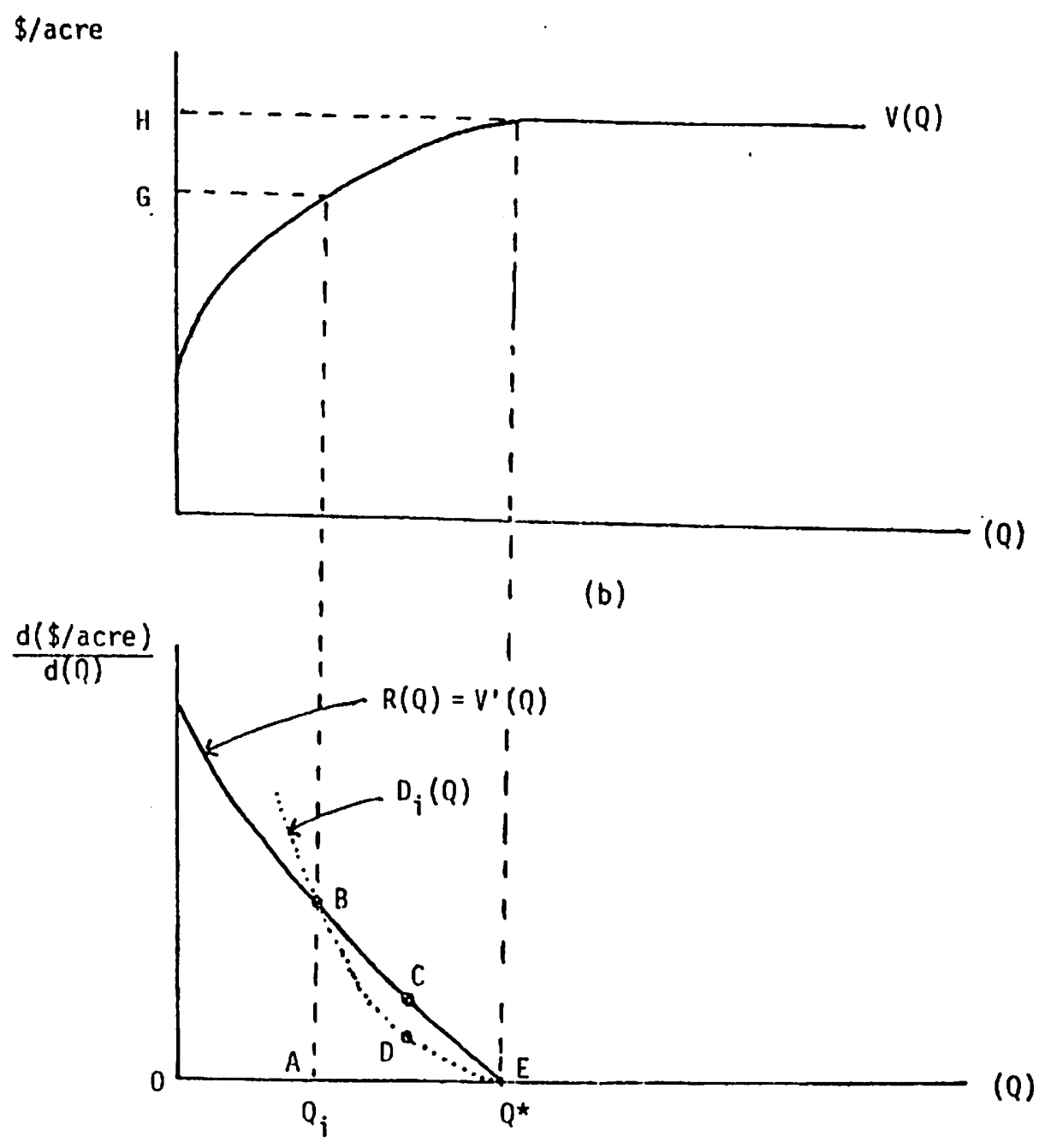


$D_{i}(Q)$ is the demand curve for distance from the railway for an individual household $i$. The first order conditions for household utility maximum require that the household 1 ive at $Q_{i}$ where: ${ }^{4}$

$$
D_{i}\left(Q_{i}\right)=R\left(Q_{i}\right)
$$

Thus $R(Q)$ may be interpreted as the locus of the equilibrium marginal willingness to pay of all households. Only if all households have identical marginal willingness to pay functions will $R(Q)$ itself be each household's demand curve. 5

In Figure 2, the benefit of removing the railway so far as properties at distance $Q_{j}$ are concerned, would actually be $A B D E$, but our measure from the observed distance from railway-property value relationship would be $A B C E \equiv G H$, which exceeds $A B D E$ and hence is an overestimate.

Thus, so far as these considerations are concerned, one would expect use of differences in property values to lead to an overestimate of the aggregate willingness to pay for removal of railway externalities. 6 Unfortunately, there does not appear to be any practical alternative to use of property values, and there is no practical way to measure the extent of the bias from use of property values.

There are two complementary approaches that can be used to estimate the differences in property values. One is the "controlled areas" approach. ${ }^{7}$ Areas with similar characteristics other than the externalities in question are chosen, and the property values in areas not affected by spillovers are compared with those in areas affected by the spillovers. The difference in value per property (or per unit area) times the number of properties (or total area) may be regarded as a measure of the benefits of removing railway spillovers. The main difficulty of this approach is to find satisfactory 
control areas. The difference in property values may be due to factors other than the spillovers under consideration.

Another approach is regression analysis based on cross-sectional data. This approach, which we shall follow in this study, provides better control of the effect of other factors on property values.

For single-family residential properties one can estimate the following function:

$$
P=f\left(x_{1}, \ldots, x_{n}\right)
$$

where $P$ is the price of a residential property and $x_{1}, \ldots, x_{n}$ are locational, housing characteristics, environmental, and other variables which affect housing prices. One of the independent variables, say $x_{i}$, will be distance from the railway. Our main hypothesis will be that because of railway externalities:

$$
\frac{\partial P}{\partial X_{i}}>0
$$

As we have mentioned before, railway pollution comes in different forms: air, noise, vibration and "visual". All of them may be assumed to vary directly with the distance from the railway.

\section{Estimation of the Value of Environmental Improvement}

To estimate the aggregate social benefits from the removal of railway externalities we employ the following function:

$$
\int_{x_{i}=0}^{\infty} f\left(x_{i}\right) g\left(x_{i}\right) d x_{i}
$$


where $f\left(x_{j}\right)$ relates discount in dollars per property to distance from railway $\left(x_{j}\right)$ and $g\left(x_{j}\right)$ shows the number of properties at each distance from the relevant railway tracks. If $f\left(x_{i}\right)$ becomes zero for $x_{i}$ greater than $D$, then the integration can be carried out from zero to $D$.

In practice we work with discrete rather than continuous functions. The following function can be used:

$$
S B=\Sigma d\left(x_{i}\right) n\left(x_{i}\right)
$$

where

$$
\begin{aligned}
S B= & \text { dollar value of social benefits from the removal of railway } \\
& \text { externalities as measured by the discount in property values; } \\
d\left(x_{i}\right)= & \text { average discount in dollars in property value between } 100 x_{i} \\
& \text { and } 100\left(x_{i}-1\right) \text { feet from the railway; } \\
n\left(x_{i}\right)= & \text { number of properties between } 100 x_{i} \text { and } 100\left(x_{i}-1\right) \text { feet from } \\
& \text { the railway. }
\end{aligned}
$$

C. RAILWAY EXTERNALITIES AND RESIDENTIAL PROPERTY VALUES:

A CASE STUDY FOR LONDON, CANADA

In this section we present a regression model of the determinants of residential property prices. Our main objective is to find out whether and to what extent a railway reduces sale prices of residential properties located in its neighbourhood. We discuss in turn: data and sample, specification of the model, and empirical results.

\section{Data and Sample}

Our sample consists mainly of single-family detached dwellings. However, a number of multiple-family dwellings (duplexes, triplexes) are 
included as well. The latter represent approximatély 15 per cent of the total sample of 285 observations.

The principal source of data is Multiple Listing Service (MLS) sheets from the files of several real estate firms in London. 8 The following information is available from MLS sheets for each property sold: (i) address of the property; (ii) physical features such as style, type of siding, number of stories, age, lot size, number and size of each type of room, garage, paved driveway, basement, type of heating, etc.; (iii) asking price and down payment requirement; (iv) financial terms and mortgages; (v) assessment and taxes; (vi) actual sale price and date of sale as recorded by the real estate firms.

To obtain distances from railways, each observation was located on city land-use maps and the distance was measured in 100 foot intervals. Since we are mainly interested in finding the relative prices of properties located at different distances from the railways, the most suitable data would be cross-sectional rather than time series. However, the data used cover a period of six years from 1967 to 1972. The main reason for using data from six years is to enlarge our sample size.

Instead of taking a random sample of all residential property sales in the city, we selected four areas within the city for study (see Figure 3). There are two reasons for this approach. First, properties which are far from the tracks will not be affected by railway externalities and hence need not be included. ${ }^{9}$ The inclusion of these transactions might create unnecessary statistical "noise". In our sample the maximum distance between track and property is about 1,400 feet. Second, in order to isolate the effect of railway facilities on property values, other locational and environmental variables are best kept constant. By selecting a sample of 
Figure 3

Map of London, Canada, Showing Sample Areas

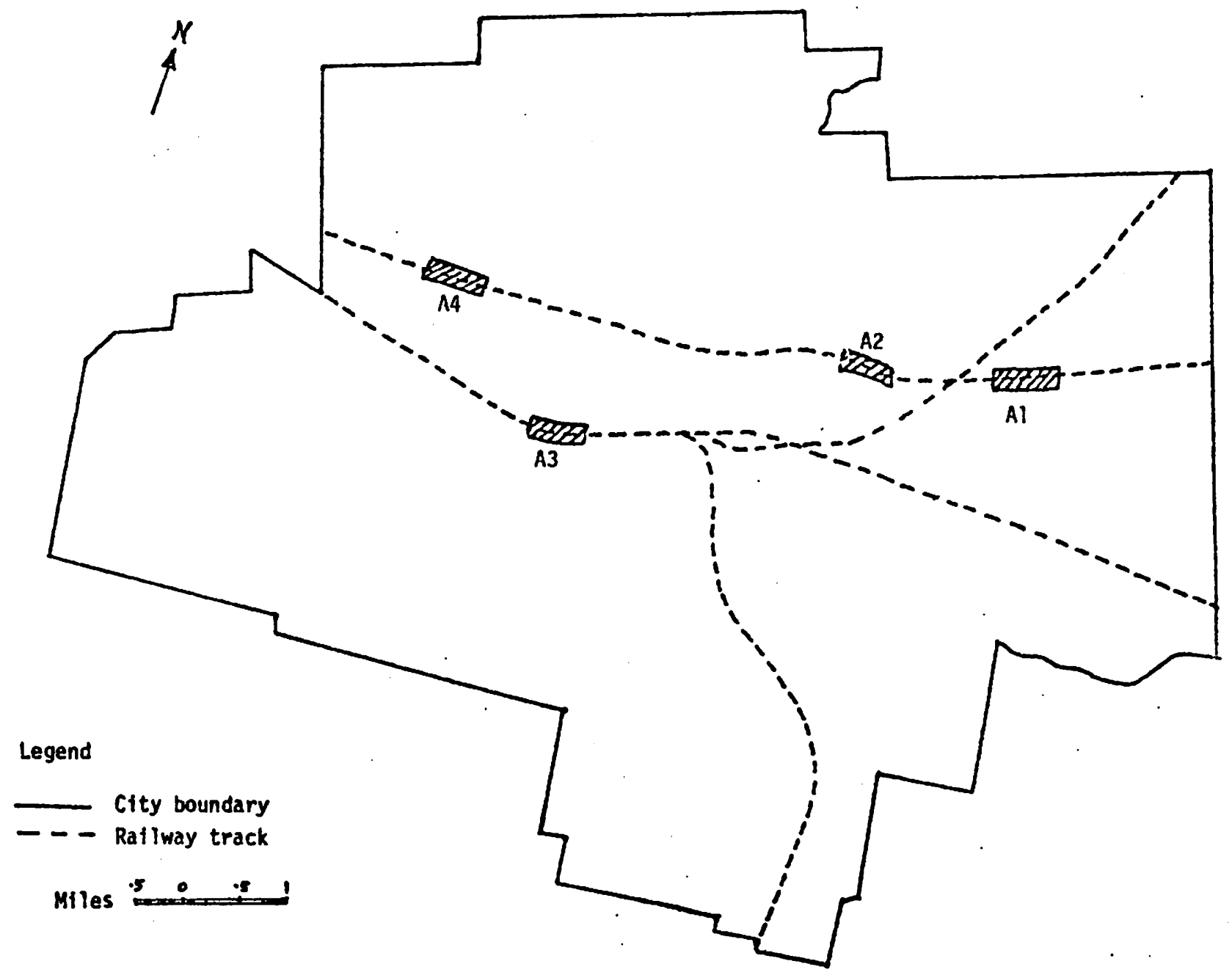

Source: Statistics Canada, Catalogue 95-742. 
given size from a limited area, we minimize the number of explanatory variables required in the regression equation.

All areas are primarily residential in use. Some commercial and/or light industrial-activities are present in areas (1), (2) and (3). Area (4) has the highest average income and average property value. Areas (1) and (4) are relatively new in comparison with areas (2) and (3).

\section{Specification of the Model}

We hypothesize that the price of a residential property is a function of the characteristics of its structure, its lot and its neighbourhood. In addition, characteristics of the existing mortgage may affect price. Also, since our data span a period of six years, account must be taken of the change in property prices over time.

Another variable which may also be included is property tax assessment. We tried this variable without success. This may be due to the fact that

London is a relatively small city under a single municipal government. ${ }^{10}$ The tax variable will not be discussed in the rest of this paper.

For empirical testing we specify our model in two basic forms:

$$
\begin{aligned}
& P=a_{0}+a_{1} x_{1}+a_{2} x_{2}+\ldots+a_{n} x_{n}+e \\
& \operatorname{Ln} P=b_{0}+b_{1} \operatorname{Ln} x_{1}+b_{2} \operatorname{Ln} x_{2}+\ldots+b_{n} \operatorname{Ln} x_{n}+e
\end{aligned}
$$

where $P$ is the sale price of an individual property, $x_{1}, \ldots, x_{n}$ are independent variables, $e$ is the error term, $L n$ is the natural logarithm operator, and $a_{0}, a_{1}, \ldots, a_{n}, b_{0}, b_{1}, \ldots, b_{n}$ are coefficients to be estimated.

A priori we cannot determine which, if either, of the specifications represents the true relationship. Both forms have been used in previous 
studies. ${ }^{11}$ We shall try both forms and some other specifications as well. We turn now to the specification of each of the variables in our regression model.

(a) Dependent variable

The dependent variable is the sale price of an individual residential property. Since we want to calculate all benefits and costs in terms of 1972 dollars, we employ a house price index developed by Davies and Jackson (1975) for London to inflate all sale prices to 1972 dollar levels. Consequently, we do not include a separate time trend as one of the independent variables. ${ }^{12}$

\section{(b) Structural variables}

The structural variables included are: age (number of years since the house was built); number of rooms (including dining room, living room, family room, bedrooms and kitchen); number of bathrooms; recreation room (dummy $=1$ if the house has a finished recreation room in the basement); basement ( $f u 11=1$, half $=.5$, none $=0)$; number of stories; fireplace (dummy $=1$ if the house is single detached, dummy $=0$ if duplex or triplex); garage (dummy $=1$ if the house has a garage); type of siding (dummy $=1$ if stone or brick).

We expect most of the structural variables to be positively related to sale price. The age variable is likely to be negatively related to sale price, except in the case where older houses may have better landscaping (we do not include this variable) and better construction. ${ }^{13}$

(c) Lot-related variables

Five lot-related variables are considered: lot size (square feet); corner lot (dummy $=1$ if it is a corner lot); distance from arterial road 
(dummy $=1$ if a property is within 3 lots of an arterial road); and distance from railway (in units of 100 feet). All of the properties are connected to the city sanitary sewers and none of them use septic tanks. Data on other lot-related variables such as landscaping and frontage are not available.

We expect lot size and distance from railway to be positively related to sale price. Distance from arterial road is expected to be negatively associated with sale price. The sign of the corner lot variable is ambiguous. $^{14}$

(d) Neighbourhood variables

Each of the areas from which observations were drawn is fairly uniform with respect to neighbourhood variables such as population density, distance from employment centres, average income, and public services. Consequently no neighbourhood variable is included in the regressions for individual areas. However, when we combine observations for all areas and run one regression, area dummies are used.

\section{(e) Mortgage variables}

If a property has a large, open, long term, low interest mortgage, it offers some financial advantages. The present discounted value of the potential saving in interest payment for the buyer is approximately

$$
S=\sum_{t=c}^{N} \frac{\left(r_{c}-r_{m}\right) M_{t}}{(1+h)^{t}}
$$

where

$r_{c}=$ interest rate on new mortgages at time of sale $(t=c)$;

$r_{m}=$ interest rate on the existing mortgage;

$M_{t}=$ outstanding mortgage at time $t$ (in dollars); 
$h=$ buyer's annual discount rate; and

$N=$ year in which existing mortgage will be paid off.

In our regression equation, we use $S^{1}=\left(r_{c}-r_{m}\right) M_{c}$ as a proxy for $S$ since we do not have data on $N$ or $h$ and the only value of $M_{t}$ we have is $M_{c}$. We expect both $S$ and $S^{1}$ to be positively related to sale price.

\section{(f) Alternative specification of some variables}

In specification (1) above a linear relationship is assumed for all variables. However, for the variables "age" and "distance from railway," it was hypothesized that the relationship with the dependent variable would likely be non-linear. Thus, in addition to specifications (1a) and (2), non-linear (quadratic) forms of these variables were tried in the otherwise linear regression (1b).

\section{Empirical Results}

The regression results are presented in Table 1. Most of the variables have the expected signs and are significantiy different from zero at the five per cent level. We shall discuss the results related to the two railway variables but not those of other variables since the latter are not of direct interest to this study.

The distance from railway (DR) variable is significant at the five per cent level and has the expected sign in all regressions. The estimated coefficients for the pooled sample of 285 observations are as follows:

$$
\begin{aligned}
& P=\ldots+\underset{(72.4)}{217} D R+\ldots \\
& P=\ldots+\underset{(239.9)}{588.7} D R-\underset{(21.1)}{35.4} D R^{2}+\ldots
\end{aligned}
$$


TABLE I

Determinants of Residential Property Price, Regression Results (Pooled Sample; Linear, Quadratic, and Log)

\begin{tabular}{|c|c|c|c|c|c|c|}
\hline $\begin{array}{l}\text { Independent } \\
\text { Variablet }\end{array}$ & (1a) & (1b) & (1c) & (1d) & (le) & (2) \\
\hline Age of house & $\begin{array}{c}-134.27 \\
(6.28)^{*}\end{array}$ & $\begin{array}{c}-500.94 \\
(3.64) \star\end{array}$ & $\begin{array}{c}-487.78 \\
(3.52) \star\end{array}$ & $\begin{array}{r}-470.75 \\
(3.36)^{\star}\end{array}$ & $\begin{array}{r}-121.14 \\
(1.15)\end{array}$ & $\begin{array}{l}-.13 \\
(5.60) *\end{array}$ \\
\hline Garage & $\begin{array}{c}576.28 \\
(1.57)\end{array}$ & $\begin{array}{c}643.66 \\
(1.87)^{*}\end{array}$ & $\begin{array}{c}701.67 \\
(1.92) *\end{array}$ & $\begin{array}{c}939.14 \\
(2.37) *\end{array}$ & $\begin{array}{c}410.09 \\
(1.50)\end{array}$ & $(.00)$ \\
\hline Bathrooms & $\begin{array}{c}1459.28 \\
(3.04) *\end{array}$ & $\begin{array}{l}1538.87 \\
(3.24)^{*}\end{array}$ & $\begin{array}{c}1583.85 \\
(3.30)^{\star}\end{array}$ & $\begin{array}{c}1565.71 \\
(3.03) *\end{array}$ & $\begin{array}{l}1174.51 \\
(3.28) *\end{array}$ & $(2.75)^{*}$ \\
\hline Lot size & $(3.92)^{*}$ & $(4.06)^{*}$ & $(2.09)^{*}$ & $(3.73) \star$ & $(5.60) \star$ & $(4.15)^{.15}$ \\
\hline No. of rooms & $\begin{array}{c}852.08 \\
(5.19)^{\star}\end{array}$ & $\begin{array}{c}827.12 \\
(5.08) *\end{array}$ & $\begin{array}{c}814.64 \\
(4.95) *\end{array}$ & $\begin{array}{c}1002.07 \\
(5.60) *\end{array}$ & $\begin{array}{l}594.60 \\
(4.86) *\end{array}$ & $(4.98)^{.35}$ \\
\hline Siding material & $\begin{array}{l}1498.87 \\
(2.75)^{\star}\end{array}$ & $\begin{array}{c}1318.42 \\
(2.43)^{\star}\end{array}$ & $\begin{array}{l}1364.46 \\
(2.51) *\end{array}$ & $\begin{array}{c}1334.97 \\
(2.34) \star\end{array}$ & $\begin{array}{l}1176.92 \\
(2.89) *\end{array}$ & $(2.76) *$ \\
\hline No. of stories & $\begin{array}{l}1245.69 \\
\quad(2.18) \star\end{array}$ & $\begin{array}{c}1266.82 \\
(2.24) \star\end{array}$ & $\begin{array}{l}1321.23 \\
(2.33) \star\end{array}$ & $\begin{array}{c}1280.35 \\
(2.09)^{*}\end{array}$ & $\begin{array}{c}952.98 \\
(2.24) *\end{array}$ & $(1.04)$ \\
\hline Basement & $\begin{array}{c}1766.91 \\
(1.91) *\end{array}$ & $\begin{array}{l}1957.43 \\
(2.14) *\end{array}$ & $\begin{array}{c}1840.01 \\
(2.00) *\end{array}$ & $\begin{array}{c}1300.18 \\
(1.32)\end{array}$ & $\begin{array}{c}1722.90 \\
(2.50) *\end{array}$ & $(2.39)^{*}$ \\
\hline Heating & $\begin{array}{c}538.73 \\
(1.18)\end{array}$ & $\begin{array}{c}456.22 \\
(1.01)\end{array}$ & $\begin{array}{c}521.20 \\
(1.14)\end{array}$ & $\begin{array}{c}677.46 \\
(1.41)\end{array}$ & $\begin{array}{c}410.56 \\
(1.21)\end{array}$ & $(1.55)$ \\
\hline Fireplace & $\begin{array}{c}688.64 \\
(1.15)\end{array}$ & $\begin{array}{c}735.12 \\
(1.26)\end{array}$ & $\begin{array}{c}798.69 \\
(1.37)\end{array}$ & $\begin{array}{c}793.40 \\
(1.29)\end{array}$ & $\begin{array}{c}1076.67 \\
(2.49)^{*}\end{array}$ & $\begin{array}{l}.03 \\
(.82)\end{array}$ \\
\hline Recreation room & $\begin{array}{r}-280.54 \\
(.35)\end{array}$ & $\begin{array}{r}-120.75 \\
(.15)\end{array}$ & $\begin{array}{r}-115.70 \\
(.45)\end{array}$ & $\begin{array}{c}35.85 \\
(.04)\end{array}$ & $\begin{array}{c}189.59 \\
(.32)\end{array}$ & $\begin{array}{l}.00 \\
(.03)\end{array}$ \\
\hline Corner lot & $\begin{array}{c}1077.92 \\
(3.00) \star\end{array}$ & $\begin{array}{l}2041.77 \\
(2.99) *\end{array}$ & $\begin{array}{l}2036.58 \\
(2.97) *\end{array}$ & $\begin{array}{c}2173.11 \\
(3.00) *\end{array}$ & $\begin{array}{c}1784.46 \\
(3.44)\end{array}$ & $(2.94) *$ \\
\hline $\begin{array}{l}\text { Distance from } \\
\text { arterial road }\end{array}$ & $\begin{array}{r}-592.44 \\
(.81)\end{array}$ & $\begin{array}{r}-499.39 \\
! .69 !\end{array}$ & $\begin{array}{c}-538.83 \\
(.75)\end{array}$ & $\begin{array}{c}-777.23 \\
(1.03)\end{array}$ & $\begin{array}{r}-641.86 \\
(1.19)\end{array}$ & $(1.02)$ \\
\hline Duplex, triplex & $\begin{array}{c}1264.99 \\
(2.05) *\end{array}$ & $\begin{array}{l}1135.98 \\
(1.86)^{*}\end{array}$ & 1117.31 & -- & $\begin{array}{c}533.16 \\
(1.16)\end{array}$ & $(1.05)$ \\
\hline Areas dumny A2 & $\begin{array}{c}532.19 \\
(1.00)\end{array}$ & $\begin{array}{c}598.63 \\
(1.14)\end{array}$ & $\begin{array}{c}572.86 \\
(1.09)\end{array}$ & $\begin{array}{c}966.36 \\
(1.68) *\end{array}$ & $\begin{array}{c}1060.94 \\
(2.65) *\end{array}$ & $(1 . .53)$ \\
\hline A3 & $\begin{array}{r}-717.15 \\
(.87)\end{array}$ & $\begin{array}{c}-616.33 \\
(.75)\end{array}$ & $\begin{array}{r}-647.54 \\
(.81)\end{array}$ & $\begin{array}{r}-480.92 \\
(.56)\end{array}$ & $\begin{array}{c}-44.05 \\
(.07)\end{array}$ & $(.03)$ \\
\hline A4 & $\begin{array}{l}7464.52 \\
(5.30) *\end{array}$ & $\begin{array}{l}4116.08 \\
(2.24)^{\star}\end{array}$ & $\begin{array}{l}4334.41 \\
(2.35) *\end{array}$ & $\begin{array}{l}3810.61 \\
(2.06) *\end{array}$ & $\begin{array}{l}8145.52 \\
(5.78) *\end{array}$ & $\begin{array}{l}.08 \\
(.87)\end{array}$ \\
\hline $\begin{array}{l}\text { Distance from } \\
\text { rallway }\end{array}$ & $\begin{array}{l}217.04 \\
(2.99) *\end{array}$ & $\begin{array}{l}588.72 \\
(2.45) *\end{array}$ & -. & $\begin{array}{c}599.93 \\
(2.26) *\end{array}$ & $\begin{array}{l}136.08 \\
(2.52) \star\end{array}$ & $(3.71)^{*}$ \\
\hline $\begin{array}{l}\text { Distance from } \\
\text { railway squared }\end{array}$ & -- & $\begin{array}{l}-35.43 \\
(1.68) \star\end{array}$ & -- & $\begin{array}{c}-35.88 \\
(1.61)\end{array}$ & - & -- \\
\hline Mortgage variable & $\begin{array}{l}-.00 \\
(.30)\end{array}$ & $\begin{array}{l}.00 \\
(.06)\end{array}$ & $\begin{array}{l}-.00 \\
(.00)\end{array}$ & $\begin{array}{l}.00 \\
(.10)\end{array}$ & $\begin{array}{l}-.00 \\
(.01)\end{array}$ & $\begin{array}{l}-.00 \\
(.34)\end{array}$ \\
\hline $\begin{array}{l}\text { Age of house } \\
\text { squared }\end{array}$ & -- & $\begin{array}{l}5.77 \\
(2.67)^{\star}\end{array}$ & $\begin{array}{l}5.57 \\
(2.55) *\end{array}$ & $\begin{array}{l}5.23 \\
(2.33)^{\star}\end{array}$ & $\begin{array}{l}.67 \\
(.40)\end{array}$ & -- \\
\hline LSDR & -- & -- & $(1.67)$ & -- & -- & -- \\
\hline LSDRR & $\cdots$ & -- & $(1.00)$ & -- & - & - \\
\hline Time trend & $\cdots$ & -- & -- & -- & $(4.10) \star$ & -- \\
\hline Constant & 6739 & 10030 & 11276 & 9964 & 107 & 7.9 \\
\hline $\mathrm{N}^{5}$ & 285 & 285 & 285 & 242 & 285 & 285 \\
\hline$R^{2}$ & .84 & .85 & .85 & .87 & .88 & .73 \\
\hline
\end{tabular}

Notes: t: The dependent variable is sale price (eqns. $l a, b, c, d, e$ ) and in (eqn. 2).

*: Indicates significant at $5 \%$ level.

t-statistics are in parentheses.

LSOR = Lot size timns distance from railway, $L S D R R=$ Lot size times distance from railway squared. 
(2)

$$
\operatorname{Ln} P=\ldots+\underset{(.014)}{.05 \ln D R+\ldots}
$$

The figures in brackets are standard errors of the individual coefficients. All these relationships show that, other things equal, residential property sale price increases with distance from the railway.

The linear and log forms do not indicate where railway adverse effects on property value would terminate. However, the quadratic form seems to indicate that discount in sale price terminates around 800 to 900 feet from the railway track. Unfortunately we have only a limited number of observations beyond 900 feet from the railway. Thus we cannot run separate regression equations for those observations which 1 ie beyond 900 feet from the railway to test the significance of the railway variable. However, we did the following test. We selected the 28 observations which lay beyond 900 feet from the railway and found their estimated sale prices based on the assumption that they were 850 feet from the railway. We compared the estimated sale prices with the actual sale prices (adjusted to 1972 dollars). Our hypothesis is that if railway externalities terminate around 850 feet from the railway, the estimated sale prices should not be significantly different from the actual sale prices. We employed two tests. The first one is a simple t-test of the difference of two means. The second one is a "correlated t-test," comparing each of the 28 pairs of actual and estimated sale prices. In each case we found no significant difference between the actual and estimated sale prices at the five per cent level.

When we test the distance from railway variable with subsamples, we find that this variable is significant at the five per cent level and has the expected sign in three of the four areas. It is a bit surprising to find that this variable is not significant in Area (4), which is a relatively 
high income area. A closer look at this area suggests why the properties near the railway may not be adversely affected. In this area, most of the tracks are buried in cuttings and are fenced off. This reduces the unpleasant noise and visual impact of the railway considerably. In the other areas, this is not the case.

Equation (1c) in Table 1 specifies the distance from railway variables in a different manner. It was hypothesized that the discount in residential sale prices due to railway externalities would be on a per square foot of lot basis rather than on a per lot basis. To test this hypothesis we specified the equation as follows:

$$
P=a+\ldots+r L S+\ldots,
$$

where

$$
\begin{aligned}
P= & \text { sale price of property; } \\
a= & \text { constant (servicing cost, etc.) } \\
r= & \text { value per square foot, which depends on distance from railway } \\
& (D R \text { ) according to a quadratic function such as } \\
& r=c_{1}+c_{2} D R+c_{3} D R^{2} \text { where } c_{1}>0, c_{2}>0, c_{3}<0 \text {; and } \\
L S= & \text { lot size (square feet). }
\end{aligned}
$$

Thus, the regression to be estimated would be:

$$
P=a+\ldots+c_{1} L S+c_{2} L S \cdot D R+c_{3} L S \cdot D R^{2}+\ldots
$$

Our regression results show that $L S$ and $L S \cdot D R$ are significant at the five per cent level. However, $L S \cdot D R^{2}$ is found to be not significant at the five per cent level.

Since our sample consists of both single-detached and duplex and 
triplex dwellings, we ran regressions with only single-detached units. The results do not change significantly from those with both types of dwellings (see equation (1d) in Table 1).

As an alternative to adjusting all sale prices into 1972 dollars, we entered the London housing price index constructed by Davies and Jackson (1975) as an independent variable. The results are illustrated in equation (le) in Table 1. The index is significant but there is no important change in the results for other variables.

Now let us state some qualifications to the above findings. The above results are based on a sample which consists mainly of single-family detached homes. It is not clear whether they would apply to high-rise apartments as well. The difference in physical structure and also in ownership (owner versus tenants) ${ }^{15}$ could mean that some of our conclusions would not hold for high-rise apartments. 16

Due to the limitations of data we probably have not succeeded in isolating the effects of some other factors on property sale prices. Hence, the distance from railway variable may pick up the effect of some correlated variables which are not included in the regression equation, such as housing quality. 17

\section{Environmental Improvement from the Removal of Railway Externalities}

To estimate the value of social benefits from the removal of railway externalities, we may make use of one of the empirical functions estimated, namely, equation (1b) in Table 1:

$$
P=\ldots+588.7 x-35.4 x^{2} \ldots
$$

Based on this relationship, column (2) of Table 2 shows the difference in 
TABLE 2

Differential in House Sale Price at Various Distances from a Railway in 1972

\begin{tabular}{|ccc|}
\hline $\begin{array}{c}(1) \\
(x), \text { Distance } \\
\text { from Railway (ft.) }\end{array}$ & $\begin{array}{c}(2)^{\mathrm{a}} \\
\text { Increase in Sale } \\
\text { Price }(\$) \text { Compared } \\
\text { to } x=0\end{array}$ & $\begin{array}{c}(3)^{\mathrm{b}} \\
\text { Discount in Sale } \\
\text { Price Compared } \\
\text { to } x=850\end{array}$ \\
\hline 50 & $\$ 285$ & $\$ 2,161$ \\
150 & 883 & 1,563 \\
250 & 1,250 & 1,196 \\
350 & 1,627 & 819 \\
450 & 1,932 & 514 \\
550 & 2,167 & 279 \\
650 & 2,329 & 117 \\
750 & 2,424 & 22 \\
850 & 2,446 & 0 \\
\hline
\end{tabular}

Notes: (a) Based on the estimated coefficient of the distance from railway variable of equation (1b) in Table 1.

(b) Based on figures in column (2). 
property value in dollars if the same house is located farther and farther from the railway. The effect of railway externalities on property values terminates about 800 to 900 feet from the track according to this relationship. Comparing two similar properties, one within 100 feet of the track, and the other over 800 feet away from the track, the latter sells for $\$ 2,161$ more than the former. In other words, the discount of the house located within 100 feet of the railway is $\$ 2,161$. Column (3) of Table 2 gives the discount in dollars of property value at various distances from the railway.

Multiplying the discount in dollars per property by the number of properties at various distances from the railway, we obtain a measure of the present discounted value of external diseconomies imposed by railways on their neighbourhood residential areas. For London, we obtained an estimate of $\$ 4.65$ million. ${ }^{18}$ In the case of railway relocation, the estimated social costs become social benefits from the removal of the railways.

It may be worthwhile to emphasize at this point that we do not consider gains or losses of property values per se as aggregate consumption benefits or costs of railway relocation. Rather, we take the differences in property value as a measure (albeit one with an upward bias, for reasons discussed above) of railway externalities. As a result of railway relocation, part or all of these externalities might be eliminated. This represents a real gain to society regardless of how property prices behave after railway relocation. 
FOOTNOTES

* The author is with the Ontario Ministry of Transportation and Communications. This paper is based on the author's Ph.D. dissertation done at the University of Western Ontario. The author would like to thank Professor Mark Frankena for detailed guidance as well as continuous encouragement. Valuable suggestions have also been received from Professors Erik Haites and Gordon Davies. All errors that remain are solely the responsibility of the author.

The removal of the railway is likely to confer environmental benefits on commercial and institutional areas as well. However, due to lack of data we cannot estimate these benefits. We expect these benefits to be positive but small compared with those conferred on residential properties.

${ }^{2}$ See, for example, Nourse $(1963,1967)$, Kitchen and Hendon (1967), Ridker and Henning (1967), Anderson and Crocker (1971).

${ }^{3}$ This point is mentioned by Edel (1971) and is the central issue in Freeman (1974) and Lind (1973).

${ }^{4}$ The second-order conditions require that the demand curve cut the marginal purchase price curve from above.

${ }^{5}$ A sufficient condition is equal incomes and identical utility functions for all households.

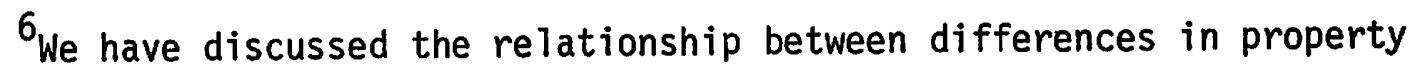
values and spillover effects in a partial equilibrium framework. A study by 
Lind (1973) using an optimal assignment land market model arrives at essentially the same kind of conclusion.

${ }^{7}$ For example, see Nourse $(1963,1967)$ and Crowley (1973).

${ }^{8}$ Published by Middlesex Real Estate Board, Ontario, Canada.

${ }^{9}$ Tests of the data indicate that railway effects reach less than 1000 feet from both sides of the railway.

${ }^{10}$ See Wales and Wiens (1974) for the rational for including the tax variable and also their findings.

11

Linear

Brigham (1965)

Ridker and Henning (1967)

Wabe (1971)

Richardson, Vipond, and Furbey (1974)
Both Linear and Log or Combination

Grether and Mieszkowski (1974)

12 We have tried a separate time trend employing the monthly housing price index for Canada. The results do not change appreciably except that the magnitude of the coefficients estimated changed.

${ }^{13}$ Some realtors have suggested that the average quality of workmanship in construction in London declined after about 1967 or 1968, e.g., use of cheaper materials such as plywood instead of hardwood for floors, less wood per house, etc. 
${ }^{14}$ In an area where commercial activities are allowed, a corner lot may command a positive premium. However, in a purely residential area, this probably would not be the case.

${ }^{15}$ Because of the short-term nature of apartment living, people may care less for railway externalities. Hence it may not be fruitful trying to detect railway externalities by looking for differences in apartment rents. Condominium sale prices could be a much better indicator. However, this form of ownership was still not popular in London during the period under consideration.

${ }^{16}$ For example, the conclusion with respect to the distance where railway externalities terminate.

17 It is conceivable that people who do not care about railway externalities also do not care about the quality of their homes (interior and exterior), so the houses near railways may be of systematically lower quality. On the other hand, people near railways may have a greater incentive to do landscaping to cut down on railway externalities, so properties near railways have systematically better landscaping (hedges, trees). In the first case, the estimated value of the coefficient of the railway variable would be biased upward, and in the second case, the bias would be in the other direction. The first case appears to be more plausible to us.

${ }^{18}$ See Poon (1976) for further details. 


\section{REFERENCES}

Anderson, R. J., and T. D. Crocker, "Air Pollution and Residential Property Values,". Urban Studies, October 1971, pp. 171-180.

Brigham, E. F., "The Determinants of Residential Land Values," Land Economics, November 1965, pp. 325-334.

Crowley, R. W., "The Effects of an Airport on Land Values," Journal of Transport Economics and Policy, May 1973, pp. 144-152.

Davies, G. W., and P. L. Jackson, A Model of the Urban Housing and Residential Land Markets, Department of Economics, University of Western Ontario, London, Canada, 1975.

Edel, M., "Land Values and the Costs of Urban Congestion: Measurement and Distribution," Social Science Information, Vo1. 10, No. 6, 1971, pp. 7-36.

Emerson, F. C., "Valuation of Residential Amenities: An Econometric Approach," The Appraisal Journal, April 1972, pp. 268-278.

Freeman, A. M., III, "On Estimating Air Pollution Control Benefits from Land Value Studies," Journal of Environmental Economics and Management, Vol. 1, No. 1, May 1974, pp. 74-83.

Grether, D. M., and P. Mieszkowski, "Determinants of Real Estate Value," Journal of Urban Economics, Apri1 1974, pp. 127-145.

Kitchen, J. W., and W. S. Hendon, "Land Values Adjacent to an Urban Neighbourhood Park," Land Economics, August 1967, pp. 357-360. 
Lind, R. C., "Spatial Equilibrium, the Theory of Rents and the Measurement of Benefits from Public Programs," Quarterly Journal of Economics, May 1973, pp. 188-207.

Nourse, H. O., "The Effect of Public Housing on Property Values in St. Louis," Land Economics, November 1963, pp. 433-441.

. Nourse, H., "The Effect of Air Pollution on House Values," Land Economics, May 1967, pp. 181-189.

Poon, C. L., "Urban Railway Relocation: An Economic Evaluation," Ph.D. dissertation, Department of Economics, University of Western Ontario, London, Canada, 1976.

Richardson, H. W., J. Vipond, and R. A. Furbey, "Determinants of House Prices," Urban Studies, June 1974, pp. 189-199.

Ridker, R., and J. Henning, "The Determination of Residential Property Values with Spectal Reference of Air Pollution," Review of Economics and Statistics, May 1967, pp. 246-257.

Wabe, J. S., "A Study of House Prices as a Measure of Establishing the Value of Journey Time, the Rate of Time Preference and the Valuation of Some Aspects of Environment in London Metropolitan Region," Applied Economics, December 1971, pp. 247-255.

Wales, T. J., and E. G. Wiens, "Capitalization of Residential Property Taxes: An Empirical Study," Review of Economics and Statistics, August 1974, pp. 329-333. 
RESEARCH PROGRAM:

IMPACT OF THE PUBLIC

SECTOR ON LOCAL ECONOMIES

The Department of Economics, University of Western Ontario, has recently mounted a long-term research program on the Impact of the Public Sector on Local Economies. The program publishes Discussion Papers and Research Studies. Copies may be obtained by writing:

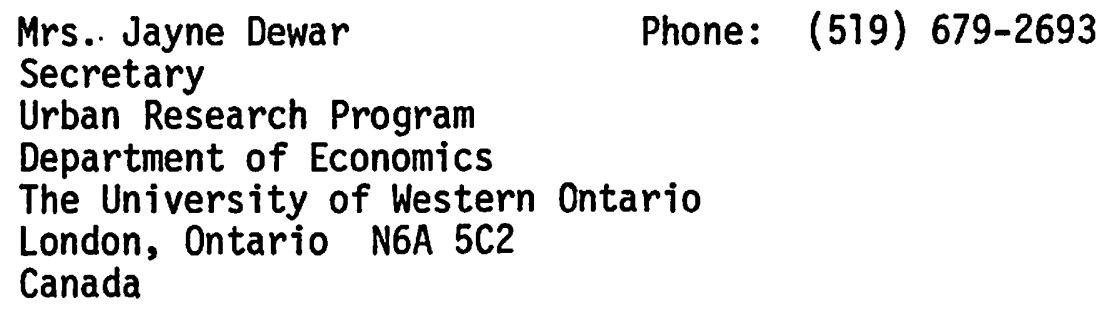

The following Discussion Papers and Research Studies are currently available:

\section{DISCUSSION PAPERS:}

* 001 P.T. Chinloy, "Hedonic Prices and Age Deterioration in Urban and Suburban Housing" (September 1975). [30 pp. - \$1.50]

002 M.W. Frankena, "Alternative Models of Rent Control" (September 1975).

003 J.R. Markusen and D.T. Scheffman, "Ownership Concentration and Market Power in Urban Land Markets" (October 1975).

004 A.J. Robson, "The Effect of Urban Structure on Ambient Pollution" (October 1975).

005 J.R. Markusen and D.T. Scheffman, "The Timing of Residential Land Development: A General Equilibrium Approach" (November 1975).

006 A.J. Robson, "Cost-Benefit Analysis and the Use of Urban Land for Transportation" (December 1975).

007 M.F. Goodchild and P.J. Booth, "Modelling Human Spatial Behavior in Urban Recreation Facility Site Location" (January 1976).

008 M.W. Johnson, "Consumer Location and Local Public Goods" (March 1976).

009 K.L. Avio and C.S. Clark, "The Supply of Property Offenses in Ontario" (April 1976). 
010 P.T. Chinloy, "Depreciation, Adverse Selection and Housing Markets" (May 1976).

011 C.L. Poon, "An Economic Evaluation of Urban Railway Relocation" (September 1976).

012 A.J. Robson, "Income Uncertainty and Urban Location" (September 1976).

013 M.W. Frankena, "An Error in Estimating Urban Density Functions Using Census Tract Data" (October 1976).

014 G.W. Davies, "The Demand for Automobiles in Canada" (December 1976).

015 M.W. Frankena, "The Demand for Urban Bus Transit in Canada" (December 1976).

016 A.J. Robson and D.T. Scheffman, "The Crunch, the Boom, and the Recreational Land Market" (January 1977).

017 A.G. Blomqvist and W. Haessel, "Small Cars, Large Cars, and the Price of Gasoline" (January 1977).

018 C. L. Poon, "Railway Externalities and Residential Property Prices" (February 1977).

RESEARCH STUDIES:

01 G.W. Davies and P.L. Jackson, "A Model of the Urban Housing and Residential Land Markets" (September 1975).

02 G.P. Schaefer, "The Urban Area Production Function and the Urban Hierarchy: The Case of Saskatchewan" (October 1975).

03 C.L. Poon, "A Cost-Benefit Study of Urban Railway Relocation" (November 1976).

04 M.W. Frankena, "Urban Transportation Economics and Canadian Public Policy" (February 1977).

* This report is out-of-print. Xerox copies can be obtained for a minimal charge of $5 \$$ per page. 